\title{
Hydrologic Conditions in Arizona During 1999-2004: A Historical Perspective
}

\section{Introduction}

Arizona's climate is prone to extreme changes that range from persistent droughts to frequent local and regional flooding. These changes are evident in hydrologic data collected. Streamflow records indicate that a drought in Arizona during 1999-2004 was the worst drought since the early 1940s and possibly earlier. Droughts result from a decrease in the number of already infrequent storms that bring moisture to Arizona. The drought conditions in the Southwestern United States over the last several years, and especially in Arizona, have resulted in several large summer fires, a decrease in potable water for some smaller communities, and depleted water available for surface water as well as ground-water recharge. An unusually wet December 2004 and January 2005 in Arizona has interrupted the multiyear drought. Dry conditions, however, still prevail in parts of Arizona. It is difficult to conclude, therefore, whether the drought is over or if it will persist.

\section{Historical and Current Hydrologic Conditions}

Although the spatial and temporal extent of droughts is somewhat difficult to determine, three severe droughts during the 20th century were recognized in a 1989 U.S. Geological Survey National Water Summary (Paulson and others, 1991). The periods of significant statewide droughts, as indicated by records from several streamflow-gaging stations, were recognized as 1932-36, 1942-64, and 1974-77 (figs. 1 and 2; table 1).

This document utilizes long-term data from streamflow-gaging stations

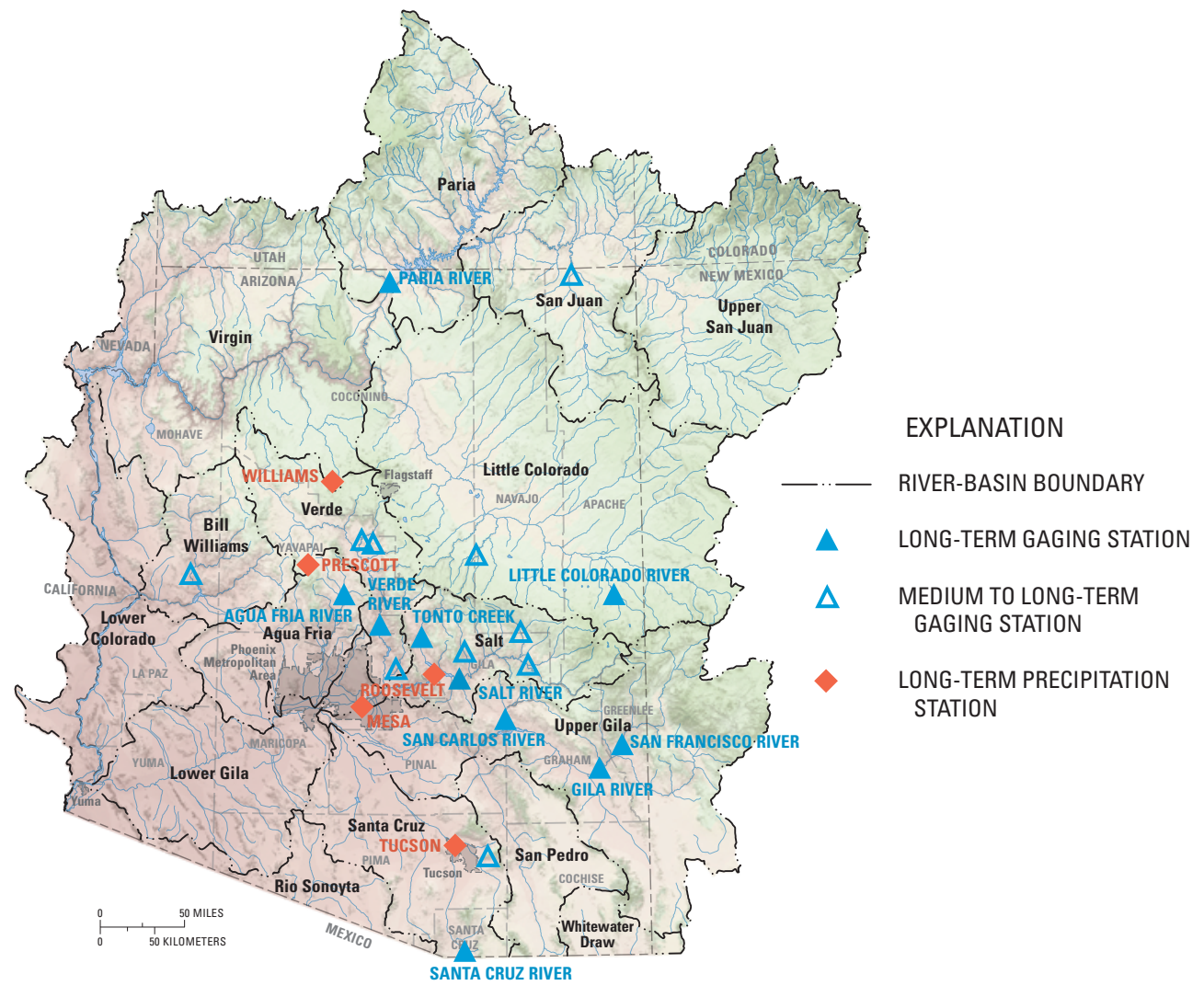

Figure 1. Locations of 10 long-term streamflow-gaging stations, 10 medium- to long-term gaging stations, and 5 long-term precipitation stations.

to compare the severity of the current drought to those indicated by Paulson and others (1991; fig. 2).

\section{Climatology in Arizona}

Precipitation in Arizona is biseasonal, having both winter and summer regimes (Hereford and others, 2002). The moisture comes from three major sources: (1) Pacific winter frontal storms that can produce significant snowpack in northern Arizona as well as flooding in the central and southern parts of
Arizona, (2) subtropical Pacific moisture (dissipating hurricanes or tropical storms) that is generally warmer and can produce regional flooding of large magnitude, and (3) convective storms that occur throughout the State during the summer months. The location and intensity of convective storms are difficult to predict as the storms can form quickly and produce large amounts of precipitation in localized areas. They also generally result in flooding in smaller basins and urban areas, but are not significant for 


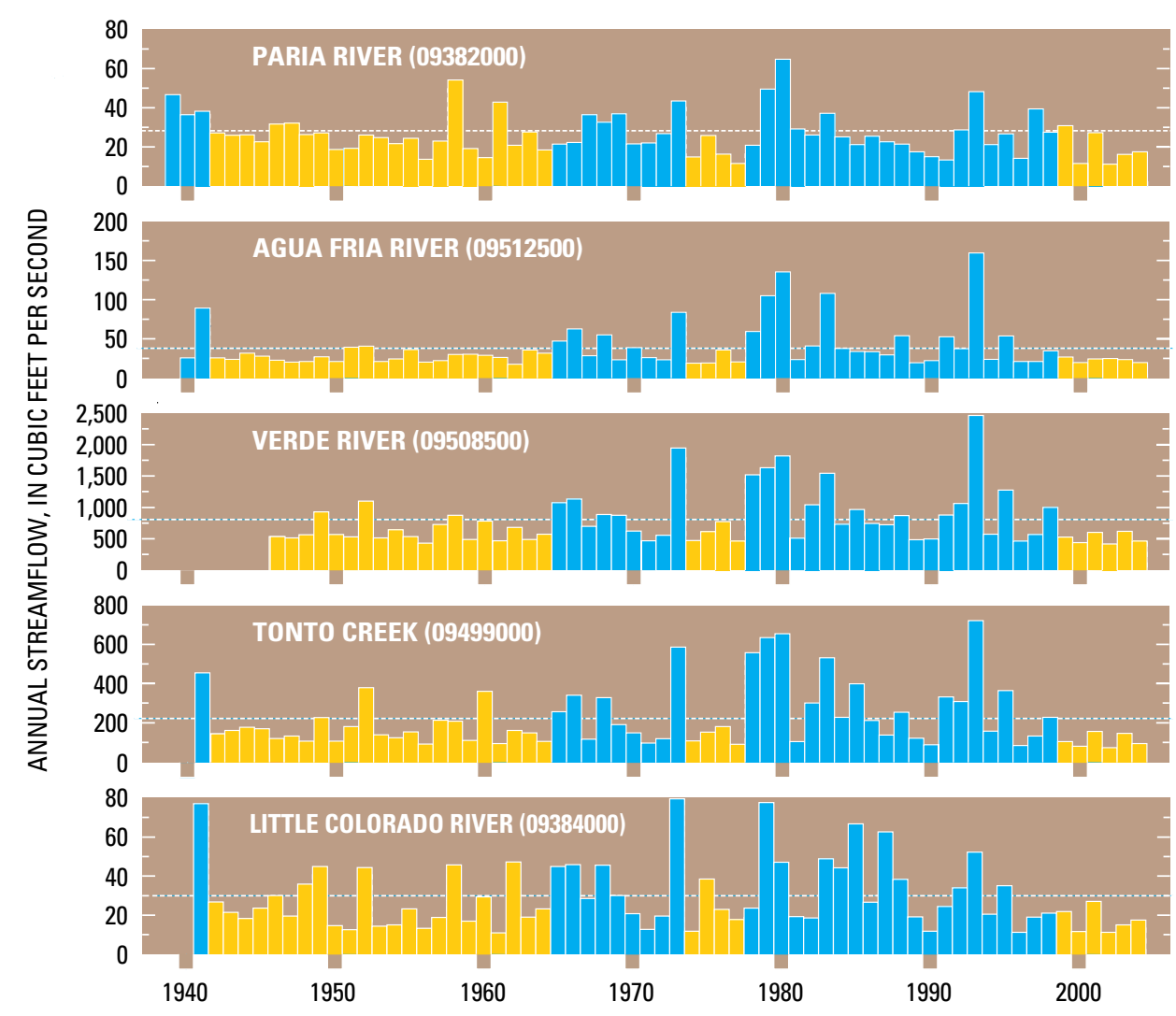

STREAMFLOW-GAGING STATIONS IN NORTHERN AND CENTRAL ARIZONA, 1939-2004-Drought periods shown in gold; horizontal line indicates long-term average. Record for the Paria River begins in 1923; data for 1923-38 not shown.

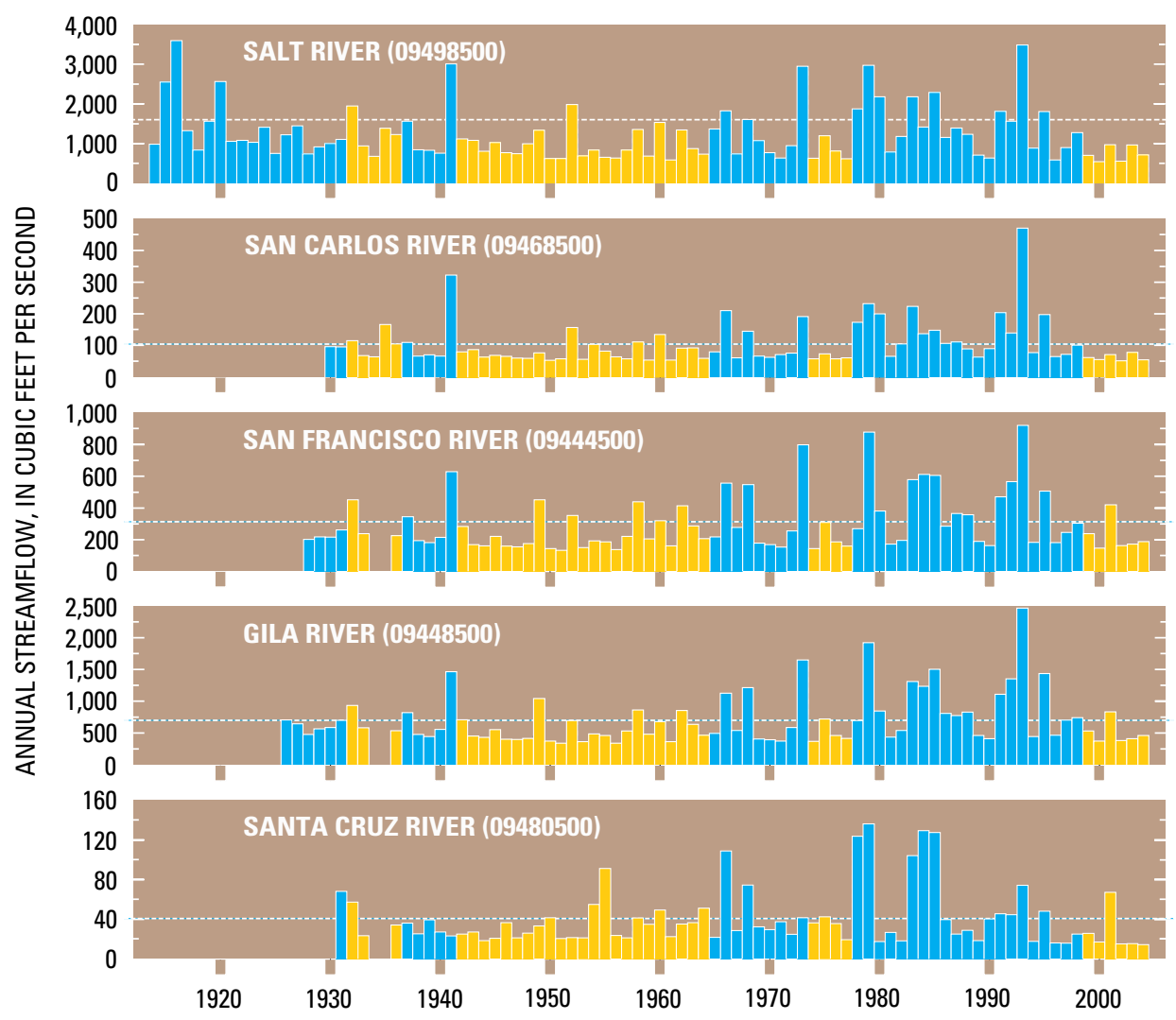

STREAMFLOW-GAGING STATIONS IN CENTRAL AND SOUTHERN ARIZONA, 1914-2004-Drought periods shown in gold; horizontal line indicates long-term average. Record for the Salt River begins in 1913; data for 1913 not shown. Gaps in plots after 1914 indicate data are not available.

Figure 2. Annual mean streamflow at 10 long-term streamflow-gaging stations in Arizona. production of higher flows in main-stem river systems (Paulson and others, 1991).

\section{Additional Information on Hydrologic Conditions in Arizona, 1999-2004}

Precipitation data acquired by the National Weather Service can serve as an indicator of drought and flood conditions. Data acquired at five long-term precipitation stations in different parts of Arizona indicate that precipitation during the last 6 years was below the long-term average (fig. 3).

Streamflow in water years (WY) 1999-2004 was compared to historical streamflow data for 20 streamflowgaging stations in Arizona for this report (table 2 and fig. 1). Included in the 20 stations are 10 long-term stations, as well as an additional 10 medium- to longterm stations (fig. 1). These 20 stations are considered index stations because they have medium to long periods of record and are little affected by flow diversions. The data for the period 1999-2004 for these 20 stations, when compared to historical data, indicate WY 2000 and WY 2002 were two of the driest years during the period of record. Annual discharge for almost all sites for individual years from 1999 to 2004 was well below long-term average conditions, indicating statewide drought conditions since the beginning of WY 1999 (October 1998). Annual discharge exceeded the long-term average only 6 times at the 20 sites from WY 1999 through WY 2004 (table 2). Annual discharge for the 20 sites over this same period of time was less than 10 percent of the average annual discharge 17 times and less than 50 percent 83 times. The drought of 1999-2004 is considered the most severe drought in Arizona since the early 1940s and possibly earlier (table 1). The average streamflow during three drought periods-1942-64, 1974-77, and 1999-2004-was compared to average streamflow for the 10 long-term index stations. Streamflow at the stations was 45 percent of the long-term flow during 1999-2004, 53 percent during 1974-77, and 68 percent during 1942-64 (fig. 2). Data for 1932-36 were insufficient for comparisons with data for 1999-2004. 
Table 1. Chronology of major and other memorable floods and droughts in Arizona, 1862-2005

[Modified from Paulson and others, 1991]

\begin{tabular}{|c|c|c|c|}
\hline $\begin{array}{l}\text { Flood or } \\
\text { drought }\end{array}$ & Date & Area affected & Remarks \\
\hline Flood & Jan. $19-23,1862$ & Gila and Colorado Rivers & $\begin{array}{l}\text { Severe at Yuma. Wet year in Verde and Bright Angel Basins, but not in upper } \\
\text { Salt River Basin }\end{array}$ \\
\hline Flood & Feb. $18-26,1891$ & Central Highlands & Phoenix and Yuma flooded. In Clifton, 18 deaths, $\$ 1$ million in damage \\
\hline Flood & Nov. 27-30, 1905 & San Francisco to Verde Rivers & $\begin{array}{l}\text { Several severe to moderate floods, particularly at Phoenix and along the lower } \\
\text { Gila River }\end{array}$ \\
\hline Flood & Jan. 19-22, 1916 & Central Highlands & $\begin{array}{l}\text { Intense rain on melting snow produced large flows in central Arizona; } 4 \text { deaths, } \\
\$ 300,000 \text { in damage }\end{array}$ \\
\hline Flood & Aug. 21, 1921 & Phoenix (Cave Creek) & $\begin{array}{l}\text { Six inches of rain in } 2 \text { days flooded } 4,000 \text { acres and the State capital building; } \\
\$ 240,000 \text { in damage }\end{array}$ \\
\hline Flood & Sept. 27-29, 1926 & San Pedro River and Mexico & Tropical storm. Peak flow $2-3$ times any other in 70 years; $\$ 450,000$ in damage \\
\hline Drought & $1932-36$ & Statewide & Effects differed among basins \\
\hline Flood & Mar. 14-15, 1941 & Central Arizona & One of several storms that caused general runoff and filled reservoirs \\
\hline Drought & $1942-64$ & Statewide & Severe long-term drought interrupted by several wet periods \\
\hline Flood & Sept. 26-28, 1962 & Brawley and Santa Rosa Washes & 1 death; $\$ 3$ million in damage, mostly to agriculture near Casa Grande \\
\hline Flood & $\begin{array}{l}\text { Dec. } 221965 \text { to } \\
\text { Jan. 2, } 1966\end{array}$ & $\begin{array}{l}\text { Verde, Salt, and Gila Rivers and } \\
\text { Rillito Creek }\end{array}$ & $\begin{array}{l}\text { First large flow through Phoenix since reservoirs were built on Verde River (1939); } \\
\$ 10 \text { million in damage }\end{array}$ \\
\hline Flood & Dec. 5-7, 1966 & $\begin{array}{l}\text { Grand Canyon to southwestern } \\
\text { Utah }\end{array}$ & $\begin{array}{l}\text { Mudflows and channel erosion damaged Indian ruins that had been undisturbed for } \\
800 \text { years }\end{array}$ \\
\hline Flood & Sept. 5-7, 1970 & Tonto Creek to Hassayampa River & $\begin{array}{l}\text { Labor Day weekend floods in recreation areas. Reservoirs stored most runoff; } \\
23 \text { deaths, } \$ 8 \text { million in damage }\end{array}$ \\
\hline Flood & Oct. $17-21,1972$ & Upper Gila River & Tropical storm; 8 deaths, $\$ 10$ million in damage \\
\hline Drought & 1974-77 & Statewide & Most severe in eastern Arizona \\
\hline Flood & July 17,1974 & Safford (Holyoke Wash) & $\begin{array}{l}\text { Thunderstorm produced flow of } 1,740 \text { cubic feet per second from } 0.85 \text {-square-mile } \\
\text { drainage basin }\end{array}$ \\
\hline Flood & Oct. 1977 to Feb. 1980 & Central and southeastern Arizona & $\begin{array}{l}\text { Seven regional floods. Phoenix declared a disaster area three times; } 18 \text { deaths, } \\
\$ 310 \text { million in damage }\end{array}$ \\
\hline Flood & July 26, 1981 & Tucson (Tanque Verde Falls) & $\begin{array}{l}\text { Flash flood at recreation area on Sunday; } 8 \text { deaths. Two larger peak discharges in the } \\
\text { same week were not noticed }\end{array}$ \\
\hline Flood & June 20 to Aug. 7,1983 & Colorado River & $\begin{array}{l}\text { Upper basin rain and snowmelt. First reservoir spill since Hoover Dam was built } \\
\text { (1935); } \$ 80 \text { million in damage }\end{array}$ \\
\hline Flood & Oct. $1-3,1983$ & $\begin{array}{l}\text { Santa Cruz to San Francisco } \\
\text { Rivers }\end{array}$ & $\begin{array}{l}\text { Record floods on } 18 \text { streams; two peak discharges doubled } 65 \text {-year-old records; } \\
8 \text { deaths, } \$ 226 \text { million in damage }\end{array}$ \\
\hline Flood & Winter 1993 & Statewide & Resulted from extremely intense El Niño; breach of Gillespie Dam on Gila River \\
\hline Drought & 1999-present (2005) & Statewide & $\begin{array}{l}\text { Extensive and abundant fires (Rodeo-Chedeski fire, for example) and decreased water } \\
\text { supplies statewide }\end{array}$ \\
\hline
\end{tabular}

Although streamflows generally were low in Arizona during 1999-2004, floods during the winter of 2005 were substantial— to the point of filling reservoirs in central Arizona. The climate of Arizona, however, naturally tends to extremes-large floods and severe drought conditions are common.

Determining whether this was an interruption to a longer drought, or the beginning of wetter years in Arizona, therefore, is difficult. Data acquired at 20 medium- to long-term streamflow-gaging stations, however, indicate the period 1999-2004 was the driest since the early 1940s and possibly earlier.

\section{-Jeff V. Phillips and \\ Blakemore E. Thomas}

\section{References}

Hereford, R., Webb, R.H., and Graham, S., 2002, Precipitation history of the Colorado Plateau region: U.S. Geological Survey Fact Sheet 119-02, 4 p.

Paulson, R.W., Chase, E.B., Roberts, R.S., Moody, D.W., 1991, National Water Summary 1988-89, Hydrologic events and floods and droughts: U.S. Geological Survey Water-Supply Paper 2375, p. 181-188.

(Figure 3 and table 2 on next page) 


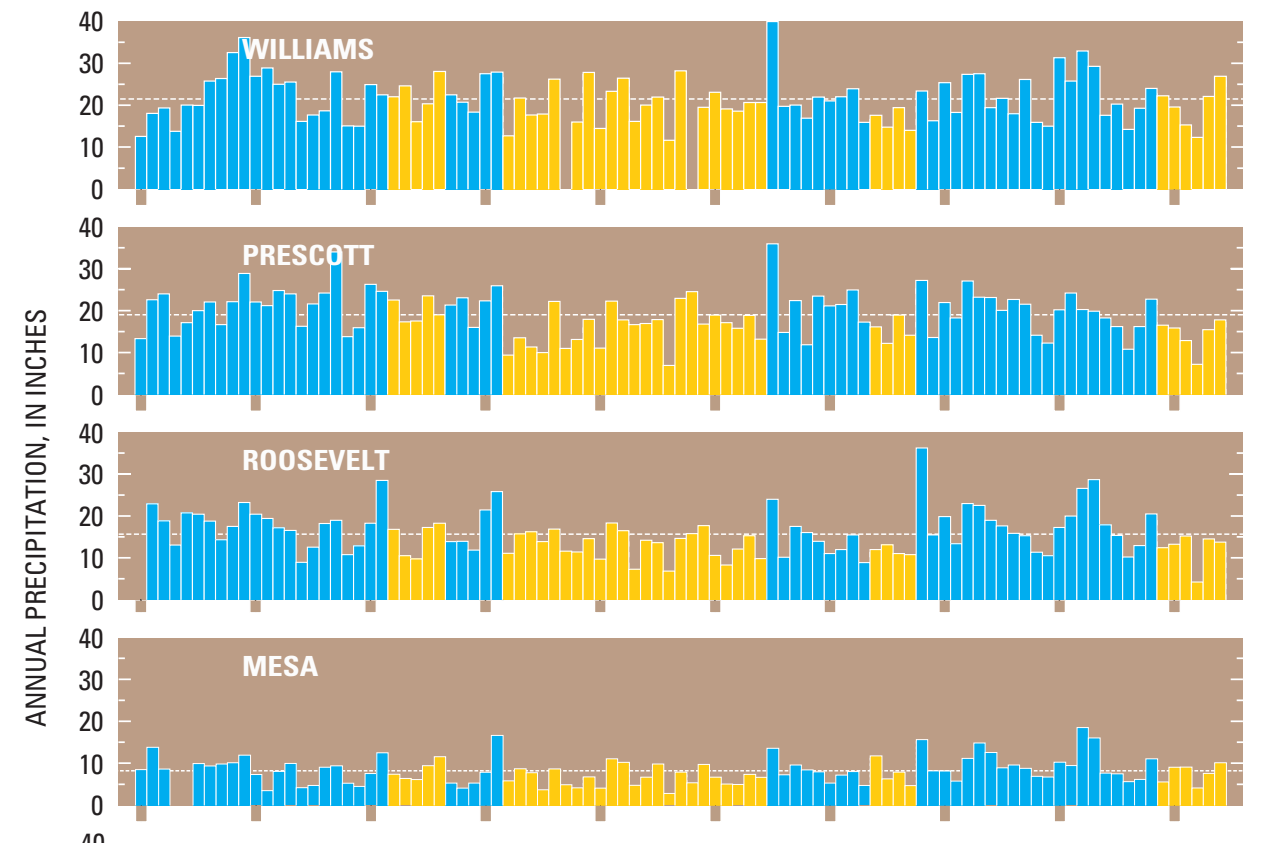

Current streamflow conditions in

Arizona can be obtained from

http://waterdata.usgs.gov/az/nwis/rt

Historical streamflow conditions can be obtained from

http://waterdata.usgs.gov/az/nwis/sw

For more information contact:

U.S. Geological Survey

Arizona Water Science Center

520 N. Park Ave., Suite 221

Tucson, Arizona 85719

Telephone: (520) 670-6671 x261

Fax: (520) 670-5592

E-mail: jvphill@usgs.gov

az.water.usgs.gov

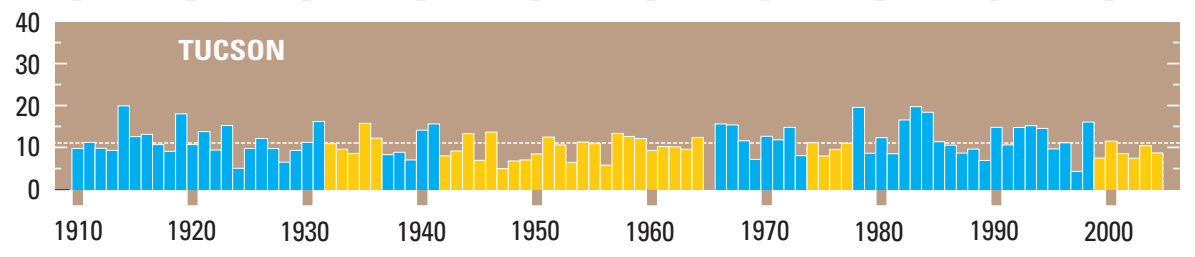

Figure 3. Annual precipitation at five long-term stations in Arizona. Drought periods shown in gold; horizontal line represents long-term average. Gaps in plots after 1910 indicate data are not available.

Table 2. Percentage of average annual discharge for 20 selected streamflow-gaging stations during water years 1999-2004

\begin{tabular}{|c|c|c|c|c|c|c|c|c|c|}
\hline \multirow[t]{2}{*}{ Site } & \multirow[t]{2}{*}{ Number } & \multirow[t]{2}{*}{ Site Name } & \multirow[t]{2}{*}{$\begin{array}{l}\text { Period of } \\
\text { Record }\end{array}$} & \multicolumn{6}{|c|}{$\begin{array}{c}\text { Percentage of average annual mean discharge for } \\
\text { indicated water year }\end{array}$} \\
\hline & & & & 1999 & 2000 & 2001 & 2002 & 2003 & 2004 \\
\hline 1 & 09382000 & Paria River at Lees Ferry & 1924-2004 & 109 & 41 & 96 & 39 & 57 & 62 \\
\hline 2 & 09512500 & Agua Fria River near Mayer & 1940-2004 & 49 & 17 & 38 & 40 & 34 & 17 \\
\hline 3 & 09508500 & Verde River below Tangle Creek & 1946-2004 & 51 & 36 & 65 & 32 & 68 & 40 \\
\hline 4 & 09499000 & Tonto Creek above Gun Creek, near Roosevelt & $1941-2004$ & 24 & 8.0 & 58 & 3.1 & 52 & 17 \\
\hline 5 & 09384000 & Little Colorado River above Lyman Lake & $1941-2004$ & 65 & 17 & 88 & 15 & 33 & 44 \\
\hline 6 & 09498500 & Salt River near Roosevelt & 1914-2004 & 40 & 22 & 70 & 23 & 70 & 41 \\
\hline 7 & 09468500 & San Carlos River near Peridot & 1930-2004 & 29 & 18 & 45 & 11 & 56 & 17 \\
\hline 8 & 09444500 & San Francisco River at Clifton & $1928-2004$ & 67 & 26 & 150 & 33 & 37 & 44 \\
\hline 9 & 09448500 & Gila River at head of Safford Valley & $1921-2004$ & 62 & 29 & 130 & 31 & 38 & 49 \\
\hline 10 & 09480500 & Santa Cruz River near Nogales & $1931-2004$ & 45 & 12 & 205 & 4.0 & 5.0 & 1.6 \\
\hline 11 & 09490500 & Black River near Fort Apache & 1958-2004 & 31 & 13 & 73 & 15 & 66 & 40 \\
\hline 12 & 09496500 & Carrizo Creek near Show Low & $1952-2004$ & 18 & 11 & 28 & 35 & 55 & 26 \\
\hline 13 & 09424450 & Big Sandy River near Wikieup & $1967-2004$ & 5.0 & 3.8 & 61 & 4.1 & 13 & 44 \\
\hline 14 & 09397500 & Chevelon Creek below Wildcat Canyon & $1948-2004$ & 17 & 6.7 & 80 & 0 & 48 & 24 \\
\hline 15 & 09504500 & Oak Creek near Cornville & 1941-2004 & 55 & 41 & 63 & 34 & 83 & 55 \\
\hline 16 & 09510200 & Sycamore Creek near Fort McDowell & 1961-2004 & 5.0 & .61 & 52 & .23 & 36 & 2.7 \\
\hline 17 & 09505350 & Dry Beaver Creek near Rimrock & 1961-2004 & 25 & 5.0 & 48 & .8 & 77 & 20 \\
\hline 18 & 09485000 & Rincon Creek near Tucson & 1953-2004 & 25 & 17 & 190 & 4.4 & 14 & 45 \\
\hline 19 & 09497980 & Cherry Creek near Globe & 1966-2004 & 35 & 16 & 53 & 12 & 35 & 16 \\
\hline 20 & 09379200 & Chinle Creek near Mexican Water & $1965-2004$ & 110 & 19 & 49 & 74 & 34 & 43 \\
\hline
\end{tabular}

